\title{
Peningkatan Motivasi Belajar Siswa Mata Pelajaran PAI melalui Metode STAD
}

\author{
ST Masropah \\ SDN Ngadirejo 01 Kota Blitar \\ Email : stmasropah@yahoo.com
}

\section{Tersedia Online di \\ http://www.jurnal.unublitar.ac.id/ index.php/briliant}

\begin{tabular}{l}
\hline Sejarah Artikel \\
\hline Diterima pada 2 April 2017 \\
Disetuji pada 6 April 2017 \\
Dipublikasikan pada 1 Mei 2017 \\
Hal. 202-213 \\
\hline
\end{tabular}

\section{Kata Kunci:}

motivasi belajar, pai, stad

\begin{abstract}
Abstrak: Penelitian ini dimaksudkan untuk menjawab permasalahan: 1) Bagaimana metode STAD dapat meningkatkan motivasi belajar siswa terhadap mata pelajaran PAI di kelas V SDN Ngadirejo 1. 2) Bagaimana peningkatan motivasi belajar siswa terhadap mata pelajaran Pendidikan Agama Islam (PAI) di kelas V SDN Ngadirejo 1. Data dalam penelitian ini diperoleh dari guru, pengamat dan siswa melalui observasi. Dengan lima komponen metode STAD dapat meningkatkan motivasi belajar siswa. Ketuntasan hasil belajar siswa secara klasikal pada siklus I rata-rata $60 \%$ meningkat menjadi $80 \%$ pada siklus II sehingga terdapat peningkatan sebesar $20 \%$
\end{abstract}

Mata pelajaran Pendidikan Agama Islam (PAI) merupakan salah satu mata pelajaran yang di dalamnya mencakup pelajaran memahami, menghayati dan juga mengamalkan materi yang diajarkan dalam kehidupan sehari-hari. Berkaitan dengan hal tersebut, kenyataan yang ada di lapangan saat ini menunjukkan bahwa mata pelajaran Pendidikan Agama Islam (PAI) mutunya masih rendah karena belum mencapai target yang diinginkan. Salah satu penyebab terjadinya hal tersebut adalah kesulitan siswa dalam memahami materi yang diajarkan. Hal ini terjadi karena guru dalam mengajarkan materi-materinya masih cenderung menggunakan metode lama yaitu hanya menjelaskan materi di depan kelas sementara siswa-siswanya duduk mendengarkan penjelasan guru. Dengan kata lain, banyak guru masih mendominasi kegiatan belajar mengajar di dalam kelas dimana mereka hanya mengutamakan pemberian teori, sebaliknya, siswa masih pasif sehingga tidak bisa mengaplikasikan dan memahami penjelasan yang mereka dapat.

Perlu dipahami bahwa seseorang bisa dikatakan telah belajar apabila terdapat perubahan pada diri orang tersebut. Perubahan tersebut bisa dalam hal pengetahuan, pemahaman, sikap, tingkah laku, ketrampilan, kecakapan, atau kebiasaan. Berkaitan dengan proses belajar seseorang, hal ini dipengaruhi oleh banyak faktor, baik faktor yang berada dalam diri individu (faktor internal) maupun faktor luar (faktor eksternal). Faktor internal bisa berupa minat (motivasi) siswa untuk belajar. Sedangkan faktor eksternal bisa dipengaruhi oleh lingkungan keluarga, lingkungan sekolah, dan juga lingkungan masyarakat. Faktor eksternal dalam hal ini erat kaitannya dengan tinggi rendahnya motivasi seseorang untuk belajar.

Motivasi itu sendiri bisa diartikan sebagai sesuatu yang menggerakkan seorang individu untuk melakukan suatu tingkah laku atau tindakan. Dalam hal belajar, motivasi amatlah sangat penting karena hal tersebut merupakan syarat 
mutlak untuk belajar. Di sekolah seringkali kita dapatkan anak yang malas untuk mengikuti mata pelajaran tertentu sehingga nilai yang didapat rendah. Hal ini disebabkan oleh kurangnya motivasi dari siswa tersebut untuk mengikuti mata pelajaran tersebut atau untuk memahami penjelasan guru. Kurangnya motivasi bisa diakibatkan oleh metode yang digunakan guru terlalu monoton, tidak menyenangkan dan kurang bisa membantu siswa tersebut untuk memahami materi yang diberikan guru yang bersangkutan.

Dengan demikian, guru harus memahami bahwa cara atau metode penyampaian materi kepada siswa sangat mempengaruhi keberhasilan siswa dalam proses belajar mereka. Berkaitan dengan hal ini pula, pada umumnya, guru sering menggunakan satu metode dalam pengajaran mereka, yaitu metode ceramah dimana metode ini diakui tidak bisa mengaktifkan peran serta siswa di dalam kelas. Hal ini mengakibatkan siswa-siswi menjadi bosan dan cenderung kurang berminat untuk mengikuti pelajaran PAI. Oleh karena itu, guru perlu menerapkan suatu metode yang menyenangkan, tidak membosankan dan bisa mempermudah mereka dalam memahami materi yang diberikan guru.

Salah satu metode yang menawarkan kelebihan tersebut adalah metode Student Teams-Achievement Divisions (STAD). STAD merupakan salah satu metode pembelajaran kooperatif yang sederhana.

Model Pembelajaran Student Teams-Achievement Divisions merupakan salah satu model pembelajaran kooperatif. STAD terdiri dari lima komponen utama: presentasi kelas, kerja tim, kuis, skor perbaikan individual dan penghargaan tim.

Motivasi adalah daya dalam diri seseorang yang mendorongnya untuk melakukan sesuatu, atau keadaan seseorang atau organisme yang menyebabkan kesiapannya untuk memulai serangkaian tingkah laku atau perbuatan. Motivasi yang diharapkan dalam penelitian ini adalah siswa semangat, senang dalam mengikuti pembelajaran Pendidikan Agama Islam

Ada dua motivasi belajar yaitu instrinsik dan ekstrinsik. Hal-hal yang dapat menimbulkan motivasi intrinsik adalah: 1) adanya kebutuhan, dengan adanya kebutuhan maka hal ini menjadi motivasi bagi anak didik untuk berbuat dan berusaha. Misalnya, seorang anak ingin mengetahui isi cerita dari buku sejarah, keinginan untuk mengetahui isi tersebut menjadi pendorong yang kuat bagi anak untuk belajar membaca 2) adanya pengetahuan tentang kemajuan sendiri 3) dengan mengetahui hasil dan presentasi diri, seperti apakah ia mendapat kemajuan atau tidak, hal ini menjadi pendorong bagi anak untuk belajar lebih giat lagi 4) adanya aspirasi atau cita-cita, setiap manusia itu tidak akan terlepas dari cita-cita.

Adapun hal-hal yang adapat menimbulkan motivasi ekstrinsik menurut Kusuma (1973) adalah: 1)ganjaran, merupakan alat pendidikan represif dan positif, ganjaran juga merupakan alat motivasi, yaitu alat yang bisa menimbulkan motivasi ekstrinsik 2) hukuman, satu-satunya hukuman yang dapat diterima dalam dunia pendidikan adalah hukuman yang bersifat memperbaiki, hukuman yang bisa menyadarkan anak sehingga dia insyaf atas kesalahan yang telah diperbuatnya 3) persaingan, apabila persaingan diadakan dalam suasana yang fair, maka hal ini akan memjadi motivasi dalam Academic Achievement. Akan tetapi, guru harus mengingat efek dari adanya persaingan ini, antara lain: murid yang terbelakang akan mengundurkan diri dan juga putus asa, murid yang tergolong sedang akan 
merasa tegang, emosional, khawatir, atau justru bersikap acuh, untuk murid yang termasuk pandai, maka persaingan yang insentif akan menimbulkan optimis terhadap kemampuan mereka.

Menurut Slavin dalam Yusron (2008 : 143) Student Team Achievement Divisions (STAD) merupakan salah satu metode pembelajaran cooperative yang paling sederhana, dan merupakan model yang baik untuk permulaan bagi para guru yang menggunakan pendekatan kooperatif. Siswa ditempatkan dalam tim belajar beranggotakan empat orang yang merupakan campuran menurut tingkat kinerjanya, jenis kelamin dan suku. Guru menyajikan pelajaran kemudian siswa bekerja dalam tim untuk memastikan bahwa seluruh anggota tim telah menguasai pelajaran tersebut. Akhirnya seluruh siswa dikenai kuis tentang materi itu dengan catatan, saat kuis mereka tidak boleh saling membantu.

Model Pembelajaran Kooperatif tipe STAD merupakan pendekatan Cooperative Learning yang menekankan pada aktivitas dan interaksi diantara siswa untuk saling memotivasi dan saling membantu dalam menguasai materi pelajaran guna mencapai prestasi yang maksimal.

Menurut Slavin (dalam Yusron, 2008 : 143) STAD terdiri atas lima komponen utama yaitu presentasi kelas, tim, kuis, skor kemajuan individual, recognisi tim. 1) Presentasi Kelas, materi dalam STAD pertama-tama diperkenalkan dalam presentasi dalam kelas. Ini merupakan pengajaran langsung seperti yang sering kali dilakukan atau diskusi pelajaran yang dipimpin oleh guru, tetapi bisa juga memasukkan presentasi audiovisual. Bedanya presentasi kelas tersebut haruslah benar-benar memberi perhatian penuh selama presentasi kelas, karena dengan demikian akan sangat membantu mereka engerjakan kuis-kuis. 2) Menetapkan siswa dalam kelompok (Tim), kelompok menjadi hal yang sangat penting dalam STAD karena didalam kelompok harus tercipta suatu kerja kooperatif antar siswa untuk mencapai kemampuan akademik yang diharapkan. Fungsi dibentuknya kelompok adalah untuk saling meyakinkan bahwa setiap anggota kelompok dapat bekerja sama dalam belajar. Lebih khusus lagi untuk mempersiapkan semua anggota kelompok dalam menghadapi tes individu. Kelompok yang dibentuk sebaiknya terdiri dari satu siswa dari kelompok atas, satu siswa dari kelompok bawah dan dua siswa dari kelompok sedang. Guru perlu mempertimbangkan agar jangan sampai terjadi pertentangan antar anggota dalam satu kelompok, walaupun ini tidak berarti siswa dapat menentukan sendiri teman sekelompoknya. 3) Tes dan Kuis, siswa diberi tes individual setelah melaksanakan satu atau dua kali penyajian kelas dan bekerja serta berlatih dalam kelompok. Siswa harus menyadari bahwa usaha dan keberhasilan mereka nantinya akan memberikan sumbangan yang sangat berharga bagi kesuksesan kelompok. 4) Skor peningkatan individual, skor peningkatan individual berguna untuk memotivasi agar bekerja keras memperoleh hasil yang lebih baik dibandingkan dengan hasil sebelumnya. Skor peningkatan individual dihitung berdasarkan skor dasar dan skor tes. Skor dasar dapat diambil dari skor tes yang paling akhir dimiliki siswa, nilai pretes yang dilakukan oleh guru sebelumnya melaksanakan pembelajaran kooperatif metode STAD. 4) Pengakuan kelompok, pengakuan kelompok dilakukan dengan memberikan penghargaan atas usaha yang telah dilakukan kelompok selama belajar. Kelompok dapat diberi sertifikat atau bentuk penghargaan lainnya jika dapat mencapai kriteria yang telah ditetapkan bersama. Pemberian penghargaan ini tergantung dari kreativitas guru. 


\section{METODE}

\section{Lokasi dan Subjek Penelitian}

Penelitian ini dilakukan di SDN Ngadirejo 1 Kecamatan Kepanjenkidul kota Blitar. Subjek penelitian ini adalah guru Pendidikan Agama Islam yang bertindak sebagai peneliti dan siswa kelas V SDN Ngadirejo 1 Kota Blitar. Siswa kelas $\mathrm{V}$ berjumlah dengan jumlah siswa perempuan dan jumlah siswa laki-laki.

\section{Rancangan Penelitian}

Peneliti membagi tahap tindakan dalam penelitian ini menjadi dua siklus. Setiap siklus terdiri dari dua pertemuan yaitu pertemuan ke-1 dan pertemuan ke-2. Setiap pertemuan diterapkan model pembelajaran kooperatif STAD.

Adapun penjabaran dari pelaksanaan dalam tiap siklus sebagai berikut : 1) tahap perencanaan, yaitu dengan menyiapkan silabus, penyusunan rencana pelaksanaan pembelajaran (RPP) yang sesuai dengan langkah-langkah STAD, menyiapkan Lembar Kerja Kelompok, membuat instrumen tes, membuat lembar observasi aktivitas guru dan lembar observasi aktivitas siswa, membuat penilaian afektif/sikap, membuat lembar angket siswa 2) tahap tindakan, peneliti melaksanakan proses pembelajaran sesuai dengan desain pembelajaran (RPP) 3) tahap pengamatan, guru sebagai peneliti meminta bantuan teman sejawat untuk melaksanakan observasi dengan mengisi lembar observasi guru dan lembar observasi siswa 4) tahap refleksi, yaitu dengan melakukan koreksi terhadap apa yang sudah dilakukan, apa yang belum dilakukan, apa saja yang sudah dicapai, masalah apa saja yang belum terpecahkan, dan tindakan apa yang harus dilakukan untuk meningkatkan kualitas proses dan hasil pembelajaran yang akan diimplementasikan pada kegiatan berikutnya.

\section{Instrumen Penelitian}

Instrumen yang digunakan pada penelitian ini berfungsi sebagai alat pengumpul data keterlaksanaan pembelajaran dengan metode STAD. Instrumen pengumpul data pelaksanaan pembelajaran yang digunakan antara lain : (1) RPP dengan langkah-langkah sesuai metode STAD. RPP berfungsi untuk merencanakan kegiatan pembelajaran yang dilakukan guru atau peneliti dalam melaksanakan pembelajaran. (2) Lembar observasi aktivitas guru yang berfungsi sebagai instrumen wajib untuk memperoleh data pelaksanaan pembelajaran. Insrrumen lembar observasi aktivitas guru berfungsi untuk menilai sejauh mana keterlaksanaan RPP dilaksanakan guru dalam proses pembelajaran. (3) Lembar Kerja kelompok dan Lembar Kerja individu (tes individu). Lembar kerja ini berfungsi untuk mengefektifkan proses pembelajaran dan memberikan permasalahan maupun pertanyaan sesuai batasan-batasan materi yang dipelajari. (4) Lembar observasi aktivitas siswa menilai aktivitas siswa dalam pembelajaran sebagai respon dari kegiatan guru dalam pembelajaran. Lembar aktivitas siswa untuk mendapatkan data tentang aktivitas siswa dalam proses pembelajaran. Instrumen ini berfungsi sebagai pengumpul data pendukung. (5) Lembar angket. Angket diperuntukkan kepada semua siswa yang merupakan subjek penelitian. Hal ini dilakukan untuk mengetahui respon siswa terhadap pelaksanaan pembelajaran dengan model STAD. 
Instrumen pengumpul data motivasi belajar siswa pada materi mengenal Asma'ul Husna menggunakan (1) Instrumen Tes individu. Tes ini berfugsi untuk mengetahui penguasaan pemahaman siswa terhadap materi setelah terlaksananya pembelajaran metode STAD. Tes disusun berdasarkan indikator yang harus dicapai. (2) Lembar penilaian sikap yang berfungsi sebagai sarana menilai sikap siswa dalam pelaksanaan pembelajaran (3) Lembar catatan lapangan, untuk mencatat temuan-temuan dalam pelaksanaan pembelajaran yang belum tercatat dalam RPP.

\section{Teknik Analisis Data dan Kriteria Keberhasilan}

Data dianalisis melalui 3 tahapan yaitu: reduksi data, penyajian data, penyimpulan hasil. Semua data yang telah terkumpul diseleksi, ditandai kemudian dipilah menjadi dua yaitu data penerapan STAD dan data peningkatan motivasi belajar.

Setelah dianalisis kemudian disajikan berupa deskripsi dan tabel, kemudian ditarik kesimpulan untuk menentukan kriteria. Kriteria keberhasilan ditentukan sebagai berikut :

$$
\begin{array}{ll}
85 \%-100 \% & : \text { Sangat baik (A) } \\
70 \%-84 \% & : \text { Baik (B) } \\
55 \%-69 \% & : \text { Cukup baik (C) } \\
45 \%-54 \% & : \text { Kurang baik (D) } \\
0 \%-44 \% & \text { : Sangat kurang baik (E) }
\end{array}
$$

\section{HASIL}

Hasil penilaian aktivitas guru pada siklus I pertemuan ke-1 menggunakan lembar observasi guru sebesar 58,33\% atau termasuk ke dalam kategori cukup atau C. Hasil penilaian observer terhadap aktivitas siswa dalam pelaksanaan pembelajaran model STAD pada Siklus I pertemuan ke-1 mencapai prosentase 50\% termasuk dalam kriteria kurang baik. Hasil kerja kelompok menunjukkan bahwa kelompok A mendapat skor 75, kelompok B mendapat skor 70 kelompok C mendapat skor 75, kelompok D mendapat skor 85, kelompok E mendapat skor 80, kelompok F mendapat skor 90 dan kelompok $G$ mendapat skor 85. Dengan demikian pemenang untuk kerja kelompok adalah kelompok $\mathrm{F}$ dengan skor 90.

Penilaian guru terhadap hasil kerja individu (tes individu) dapat dilihat ketuntasan klasikal sebesar 53,33\% atau belum mencapai ketuntasan klasikal (85\%). Data selengkapnya dapat dilihat pada lampiran tabel 4.5 dan rekap tersebut dapat dilihat dalam tabel di bawah ini.

Tabel 1 Hasil Rekapitulasi Tes Individu

\begin{tabular}{ll}
\hline Keterangan & Nilai \\
\hline Jumlah nilai & 2150 \\
Rata-rata & 71.67 \\
Jumlah siswa tuntas & 16 \\
Jumlah siswa belum tuntas & 14 \\
Prosentase ketuntasan klasikal & $53.33 \%$ \\
\hline
\end{tabular}

Hasil penilaian afektif siswa meliputi penilaian sikap kerja sama dan keaktifan siswa saat mengikuti pembelajaran dengan model STAD. Dari hasi

206 BRILIANT: Jurnal Riset dan Konseptual

Volume 2 Nomor 2, Mei 2017 
penilaian tersebut dapat diketahui terdapat dua siswa yang sudah membudaya dalam hal kerjasama dan keaktifannya.

Tabel 2 Hasil rekapitulasi penilaian sikap

\begin{tabular}{|c|c|c|c|c|c|c|c|c|c|c|}
\hline \multirow[b]{3}{*}{ No. } & \multirow{3}{*}{$\begin{array}{c}\text { Nama Peserta } \\
\text { Didik }\end{array}$} & \multicolumn{8}{|c|}{ Kriteria } & \\
\hline & & \multicolumn{4}{|c|}{ Kerjasama } & \multicolumn{4}{|c|}{ Keaktifan } & \\
\hline & & MK & $\mathrm{MB}$ & $\mathrm{MT}$ & BT & MK & $\mathrm{MB}$ & MT & BT & \\
\hline & Jumlah Siswa & 2 & 8 & 13 & 7 & 2 & 8 & 12 & 8 & 60 \\
\hline
\end{tabular}

Catatan lapangan selama pembelajaran berlangsung sebagai berikut : (1) guru belum menggunakan media yang dapat menarik minat belajar siswa. Saat presentasi kelas oleh guru, guru hanya menggunakan media papan tulis dan buku sumber belajar (2) Penempatan siswa dalam kelas belum tepat karena beberapa siswa membelakangi papan tulis sehingga menyulitkan siswa untuk konsentrasi pada saat guru menyajikan materi. (3) Ditemukan sebagian besar siswa masih takut untuk bertanya dan sulit untuk mengemukakan pendapat.

Penilaian aktivitas guru pada siklus I pertemuan ke-2 menggunakan lembar observasi guru. Aspek yang diamati dalam lembar observasi guru dengan menerapkan model STAD sebanyak dua belas aspek. Dari aspek tersebut terdapat sembilan aspek yang sudah muncul dan tiga aspek yang belum muncul. Hasil observasi aktivitas guru pada siklus I pertemuan ke-2 dengan menerapkan model STAD yaitu sebesar $75 \%$ termasuk ke dalam kategori baik atau B

Penilaian observer dalam lembar observasi aktivitas siswa terdapat sepuluh aspek. Kesepuluh aspek tersebut merupakan respon dari aktivitas yang dilaksanakan guru dalam proses pembelajaran mulai dari kegiatan awal, kegiatan inti dan kegiatan akhir. Dari kesepuluh aspek tersebut terdapat tujuh aspek yang sudah muncul dan ada tiga aspek yang belum muncul. Hasil penilaian observer terhadap aktivitas siswa dalam pelaksanaan pembelajaran model STAD pada Siklus I pertemuan ke-2 mencapai prosentase $70 \%$ termasuk dalam kriteria $\operatorname{cukup}(\mathrm{C})$.

Hasil penilaian guru terhadap hasil kerja kelompok menunjukkan bahwa kelompok A mendapat skor 85, kelompok B mendapat skor 90 kelompok C mendapat skor 85 , kelompok D mendapat skor 100, kelompok E mendapat skor 80, kelompok F mendapat skor 95 dan kelompok $\mathrm{G}$ mendapat skor 85. Dengan demikian pemenang untuk kerja kelompok adalah kelompok $\mathrm{F}$ dengan skor 100.

Penilaian guru terhadap hasil kerja individu (tes individu) diberikan kepada setiap siswa dengan jumlah soal sebanyak lima butir. Tes dilakukan dengan alokasi waktu sepuluh menit. Hasil penilaian tes akhir memperoleh nilai rata-rata 71,67 dengan perolehan nilai tertinggi 100 dan nilai terendah 40. Jumlah siswa yang sudah tuntas sebanyak 16 siswa dan siswa yang belum tuntas sebanyak 14 siswa. Jadi dari hasil rekapitulasi penilaian tes individu dapat dilihat ketuntasan klasikal sebesar 53,33\% atau belum mencapai ketuntasan klasikal (85\%). Keterangan ini dapat dilihat dalam tabel di bawah ini. 
Tabel 3 Hasil Rekapitulasi Tes Individu

\begin{tabular}{ll}
\hline Keterangan & Nilai \\
\hline Jumlah nilai & 2260 \\
Rata-rata & 75.33 \\
Jumlah siswa tuntas & 20 \\
Jumlah siswa belum tuntas & 10 \\
Prosentase ketuntasan klasikal & $66.67 \%$ \\
\hline
\end{tabular}

Hasil penilaian afektif siswa meliputi penilaian sikap kerjasama dan keaktifan siswa saat mengikuti pembelajaran dengan model STAD. Dari hasil penilaian tersebut dapat diketahui bahwa dalam hal kerjasama terdapat empat siswa yang sudah membudaya, delapan siswa mulai berkembang, limabelas siswa mulai terlihat dan tiga siswa belum terlihat. Untuk kriteria keaktifan siswa terdapat tiga siswa yang sudah membudaya, sebelas siswa mulai berkembang duabelas siswa mulai terlihat dan empat siswa masih belum terlihat. Prosentase keberhasilannya masih $61 \%$ termasuk kriteria cukup atau C.

Catatan lapangan selama pembelajaran berlangsung sebagai berikut : (1) guru sudah melaksanakan kegiatan awal dengan baik (2) guru sudah menggunakan media sederhana namun dapat menarik minat belajar siswa. (3) Penempatan siswa dalam kelas sudah lebih baik dari pertemuan sebelumnya karena siswa sudah tidak ada yang membelakangi papan tulis ketika melakukan kerja kelompok (3) beberapa siswa sudah mulai berani bertanya kepada guru tentang hal yang belum dimengerti.

Berdasarkan hasil observasi dan analisis data serta data pendukung pada siklus I pertemuan 1 dan pertemuan 2 maka refleksi pada siklus I adalah sebagai berikut: (1) langkah-langkah pembelajaran yang dilaksanakan guru dengan menggunakan model STAD sudah mengalami peningkatan dari pertemuan $1 \mathrm{ke}$ pertemuan 2, namun guru masih perlu meningkatkan kualitas pembelajaran yaitu dengan menambahkan penggunaan media yang sesuai sehingga hasil yang diperoleh bisa lebih maksimal, (2) hasil belajar siswa pada siklus I pertemuan 2 menunjukkan peningkatan nilai akhir rata-rata kelas daripada siklus I pertemuan 1 yakni 71,67 dan pada siklus I pertemuan 2 meningkat menjadi 75,33. (3) aktivitas siswa selama proses pembelajaran dengan menggunakan model pembelajaran $S T A D$ sudah menunjukkan peningkatan dari pertemuan 1 ke pertemuan 2, tetapi masih ada beberapa aspek yang belum nampak diantaranya siswa belum berani untuk menyampaikan pendapat terhadap jawaban kelompok lain, siswa masih ragu dan kurang berani untuk menyampaikan kesan atau pendapat mengenai pembelajaran.

Hasil penilaian aktivitas guru pada siklus II pertemuan ke-1 menggunakan lembar observasi guru. Aspek yang diamati dalam lembar observasi guru dengan menerapkan model STAD sebanyak dua belas aspek. Dari aspek tersebut terdapat dua aspek yang belum muncul dan sepuluh aspek yang sudah muncul atau tingkat keberhasilan sebesar $83 \%$ atau termasuk ke dalam kategori baik atau $\mathrm{B}$.

Penilaian observer dalam lembar observasi aktivitas siswa terdapat sepuluh aspek. Kesepuluh aspek tersebut merupakan respon dari aktivitas yang dilaksanakan guru dalam proses pembelajaran mulai dari kegiatan awal, kegiatan inti dan kegiatan akhir. Dari kesepuluh aspek tersebut terdapat delapan aspek

208 BRILIANT: Jurnal Riset dan Konseptual Volume 2 Nomor 2, Mei 2017 
yang sudah muncul dan ada dua aspek yang belum muncul atau tingkat keberhasilan mencapai prosentase $80 \%$ termasuk dalam kriteria baik.

Hasil penilaian guru terhadap hasil kerja kelompok menunjukkan bahwa kelompok A mendapat skor 90, kelompok B mendapat skor 90 kelompok C mendapat skor 85, kelompok D mendapat skor 95, kelompok E mendapat skor 80, kelompok F mendapat skor 100 dan kelompok G mendapat skor 80. Dengan demikian pemenang untuk kerja kelompok adalah kelompok F dengan skor 100.

Penilaian guru terhadap hasil kerja individu (tes individu) diberikan kepada setiap siswa dengan jumlah soal sebanyak sepuluh butir. Tes dilakukan dengan alokasi waktu sepuluh menit. Hasil penilaian tes akhir memperoleh nilai rata-rata 80,33 dengan perolehan nilai tertinggi 100 dan nilai terendah 60. Jumlah siswa yang sudah tuntas sebanyak 22 siswa dan siswa yang belum tuntas sebanyak 8 siswa. Jadi dari hasil rekapitulasi penilaian tes individu dapat dilihat ketuntasan klasikal sebesar $73,33 \%$ atau belum mencapai ketuntasan klasikal (85\%). Data selengkapnya dapat dilihat di lampiran tabel 4.20 dan rekap tersebut dapat dilihat dalam tabel di bawah ini.

Tabel 4 Hasil Rekapitulasi Tes Individu

\begin{tabular}{ll}
\hline Keterangan & Nilai \\
\hline Jumlah nilai & 2410 \\
Rata-rata & 80.33 \\
Jumlah siswa tuntas & 22 \\
Jumlah siswa belum tuntas & 8 \\
Prosentase ketuntasan klasikal & 73.33 \\
\hline
\end{tabular}

Hasil penilaian afektif siswa meliputi penilaian sikap kerjasama dan keaktifan siswa saat mengikuti pembelajaran dengan model STAD. Dari hasil penilaian tersebut dapat diketahui bahwa dalam hal kerjasama terdapat lima siswa yang sudah membudaya, limabelas siswa mulai berkembang, sepuluh siswa mulai terlihat. Untuk kriteria keaktifan siswa terdapat empat siswa yang sudah membudaya, enambelas siswa mulai berkembang, sembilan siswa mulai terlihat dan satu siswa masih belum terlihat. Prosentase keberhasilan70\% termasuk kriteria baik atau B.

Catatan lapangan selama pembelajaran berlangsung sebagai berikut : (1) guru sudah melaksanakan pembelajaran menerapkan model STAD dengan baik (2) posisi tempat duduk siswa telah lebih baik sehingga tidak ada siswa yang membelakangi papan tulis. (3) Siswa sudah mulai terbiasa melaksanakan pembelajaran dengan model STAD

Penilaian aktivitas guru pada menggunakan lembar observasi uru. Aspek yang diamati dalam lembar observasi guru dengan menerapkan model STAD sebanyak dua belas aspek. Semua aspek telah muncul pada pertemuan hari itu kecuali satu yaitu pengakuan kelompok (memberikan penghargaan atas usaha yang telah dilakukan kelompok. Hasil observasi aktivitas guru pada siklus I pertemuan ke-2 dengan menerapkan model STAD yaitu sebesar 91,67\% termasuk ke dalam kategori sangat baik atau A.

Penilaian observer dalam lembar observasi aktivitas siswa terdapat sepuluh aspek. Kesepuluh aspek tersebut merupakan respon dari aktivitas yang dilaksanakan guru dalam proses pembelajaran mulai dari kegiatan awal, kegiatan 
inti dan kegiatan akhir. Pada Siklus II pertemuan ke-2 semua aspek tersebut telah muncul, kecuali aspek yang terakhir yaitu siswa berani mengungkapakan kesan dan saran mengenai pembelajaran sehingga diperoleh prosentase keberhasilan sebesar $90 \%$, termasuk dalam kategori sangat baik (A).

Hasil penilaian guru terhadap hasil kerja kelompok menunjukkan bahwa kelompok A mendapat skor 75, kelompok B mendapat skor 90 kelompok C mendapat skor 85, kelompok D mendapat skor 80, kelompok E mendapat skor 80, kelompok $\mathrm{F}$ mendapat skor 95 dan kelompok $\mathrm{G}$ mendapat skor 85. Dengan demikian pemenang untuk kerja kelompok adalah kelompok $\mathrm{F}$ dengan skor 100.

Penilaian guru terhadap hasil kerja individu (tes individu) diberikan kepada setiap siswa dengan jumlah soal sebanyak sepuluh butir. Tes dilakukan dengan alokasi waktu limabelas menit. Hasil penilaian tes akhir memperoleh nilai rata-rata 83,67 dengan perolehan nilai tertinggi 100 dan nilai terendah 60. Jumlah siswa yang sudah tuntas sebanyak 26 siswa dan siswa yang belum tuntas sebanyak 4 siswa. Jadi dari hasil rekapitulasi penilaian tes individu dapat dilihat ketuntasan klasikal sebesar $86,67 \%$. Prosentase tersebut menunjukkan bahwa pembelajaran telah mencapai ketuntasan klasikal, sehingga tidak perlu diulang.

Tabel 5 Hasil Rekapitulasi Tes Individu

\begin{tabular}{ll}
\hline Keterangan & Nilai \\
\hline Jumlah nilai & 2510 \\
Rata-rata & 83.67 \\
Jumlah siswa tuntas & 26 \\
Jumlah siswa belum tuntas & 4 \\
Prosentase ketuntasan klasikal & 86.67 \\
\hline
\end{tabular}

Hasil penilaian afektif siswa meliputi penilaian sikap kerjasama dan keaktifan siswa saat mengikuti pembelajaran dengan model STAD. Dari hasil penilaian tersebut dapat diketahui bahwa dalam hal kerjasama terdapat empat siswa yang sudah membudaya, delapan siswa mulai berkembang, limabelas siswa mulai terlihat dan tiga siswa belum terlihat. Untuk kriteria keaktifan siswa terdapat tiga siswa yang sudah membudaya, sebelas siswa mulai berkembang duabelas siswa mulai terlihat dan empat siswa masih belum terlihat. Prosentase keberhasilannya masih $61 \%$ termasuk kriteria cukup atau C.

Catatan lapangan selama pembelajaran berlangsung sebagai berikut : (1) guru sudah melaksanakan kegiatan awal, kegiatan inti dan kegiatan akhir dengan baik (2) guru sudah menggunakan media (3) Penempatan siswa dalam kelas sudah lebih baik dari pertemuan sebelumnya karena siswa sudah tidak ada yang membelakangi papan tulis ketika melakukan kerja kelompok (4) beberapa siswa sudah berani bertanya kepada guru tentang hal yang belum dimengerti (5) siswa sudah terbiasa dengan kegiatan pembelajaran dengan model STAD

Berdasarkan hasil observasi dan analisis data serta data pendukung pada siklus I pertemuan 1 dan pertemuan 2 maka refleksi pada siklus II adalah sebagai berikut: (1) langkah-langkah pembelajaran yang dilaksanakan guru dengan menggunakan model STAD sudah mengalami peningkatan dari pertemuan $1 \mathrm{ke}$ pertemuan 2, (2) hasil belajar siswa pada siklus II pertemuan 2 menunjukkan 
peningkatan nilai akhir rata-rata kelas daripada siklus I pertemuan 1 (3) aktivitas siswa selama proses pembelajaran dengan menggunakan model pembelajaran STAD sudah menunjukkan peningkatan dari pertemuan 1 ke pertemuan 2 .

\section{PEMBAHASAN}

Model Pembelajaran Kooperatif tipe STAD merupakan pendekatan Cooperative Learning yang menekankan pada aktivitas dan interaksi diantara siswa untuk saling memotivasi dan saling membantu dalam menguasai materi pelajaran guna mencapai prestasi yang maksimal.

STAD memiliki lima komponen utama yaitu presentasi kelas, menetapkan siswa dalam kelompok (Tim), Tes dan Kuis, skor peningkatan individual dan pengakuan kelompok. Dengan kelima komponen tersebut diterapkan dalam pembelajaran PAI kelas V SDN Ngadirejo 1, guru dan siswa lebih termotivasi dan semangat dalam belajar.

Dengan metode STAD pada pembelajaran PAI siswa kelas V SDN Ngadirejo 1 semester 1 tahun ajaran 2016/2017 motivasi belajar siswa meningkat. Peningkatan motivasi tersebut dapat diketahui dari hasil obsevasi kegiatan siswa yang mengalami peningkatan. Hasil Penelitian dibahas sebagai berikut : 1) Pada siklus I pertemuan ke-1 masih ada kekurangan pada aktivitas guru, yaitu guru belum menyiapkan media yang tepat, belum memotivasi siswa untuk siap belajar, belum memberi pengakuan kelompok. Guru juga kurang memberi kesempatan untuk bertanya kepada siswa sehingga siswa kurang aktif mengikuti pembelajaran. Penataan tempat duduk untuk siswa pada saat kegiatan kelompok juga masih kurang tepat karena beberapa siswa masih membelakangi papan tulis. Hal ini mengakibatkan siswa kesulitan ketika akan memperhatikan penjelasan dari guru. 2) Pada siklus I pertemuan ke-2 sudah ada peningkatan dalam proses pembelajaran dengan metode STAD. Guru sudah menggunakan media yang sesuai untuk pembelajaran, guru sudah memotivasi siswa untuk lebih siap belajar, guru sudah memberi pengakuan kelompok, guru juga sudah menata tempat duduk siswa sehingga tidak ada siswa yang membelakangi papan tulis. Namun guru belum melaksanakan tahap skor peningkatan individu. Siswa belum terlihat aktif mengikuti pembelajaran, banyak siswa yang belum berani mengungkapkan pendapat terhadap jawaban kelompok lain. 3) Pada siklus II pertemuan ke-1 kegitan pembelajaran dengan metode STAD telah jauh lebih baik, namun guru belum melaksanakan refleksi dan skor peningkatan individu. 4) Pada siklus II pertemuan ke-2 kegiatan pembelajaran dengan metode STAD telah terlaksana dengan baik. Hampir semua komponen telah terlaksana dengan baik. Siswa lebih termotivasi mengikuti pembelajan PAI. Sehingga ketuntasan belajar klasikal siswa telah meningkat dan sesuai dengan KKM.

Peningkatan motivasi belajar siswa terhadap mata pelajaran PAI dapat diketahui dari meningkatnya ketuntasan belajar siswa secara klasikal yaitu pada siklus I rata-rata $60 \%$ menjadi $80 \%$ pada siklus II sehingga terdapat peningkatan sebesar $20 \%$.

\section{KESIMPULAN}

Berdasarkan hasil penelitian tindakan kelas di kelas V SDN Ngadirejo 1 maka dapat diambil simpulan sebagai berikut: 1) Dalam melaksanakan pembelajaran PAI pada materi mengenal Nama-nama Allah dan Kitab-kitab 
Allah, dengan lima komponen metode STAD maka dapat meningkatkan motivasi belajar siswa. Siswa menjadi lebih aktif dan hasil belajar mengalami peningkatan. Dari kegiatan Siklus I pertemuan ke-1 dan ke-2, dan Siklus II pertemuan ke-1 dan ke-2 terlihat peningkatan motivasi belajar siswa. 2) Penerapan metode STAD pada materi mengenal Nama-nama Allah dan Kitab-kitab Allah kelas V SDN Ngadirejo 1 tahun pelajaran 2016/2017 dapat meningkatkan motivasi belajar siswa. Peningkatan motivasi tersebut dapat diketahui dari keaktifan belajar dan ketuntasan hasil belajar siswa yang mengalami peningkatan. Ketuntasan hasil belajar siswa secara klasikal pada siklus I rata-rata $60 \%$ meningkat menjadi $80 \%$ pada siklus II sehingga terdapat peningkatan sebesar $20 \%$.

\section{SARAN}

Penelitian ini diharapkan dapat bermanfaat bagi semua pihak. Oleh sebab itu, peneliti memberikan saran sebagai berikut : 1) Untuk melaksanakan metode STAD memerlukan persiapan yang cukup matang, sehingga peneliti harus mampu menentukan materi yang tepat untuk dilaksanakan dengan metode STAD 2) Sebaiknya para guru khususnya guru Pendidikan Agama Islam menerapkan metode bervariasi, salah satunya menggunakan metode STAD dalam pembelajaran. Penggunaan metode STAD dapat meningkatkan motivasi belajar siswa.

\section{DAFTAR RUJUKAN}

Departemen Pendidikan dan Kebudayaan. 1984. Kamus Umum Bahasa Indonesia. Jakarta: PN Balai Pustaka.

Departemen Pendidikan Nasional. 2002. Petunjuk pelaksanaan Penilaian Kelas. Jakarta: Departemen Pendidikan Nasional.

Djamarah, Syaiful Bahri. 2006. Guru dan Anak dalam Interaksi Edukatif : Suatu Pendekatan Teoritis Psikologis. Jakarta: PT. Rineka Cipta.

Ellyana. 2007. Penerapan Pembelajaran Kooperatif Model STAD untuk Meningkatkan Motivasi, Aktivitas dan Hasil Belajar Biologi Siswa Kelas VII-A SMP PGRI Purwodadi Kabupaten Pasuruan. Skripsi tidak diterbitkan. Malang: Universitas Negeri Malang.

Hollingsworth, Pat dan Lewis, Gina. 2008. Pembelajaran Aktif. Jakarta: PT. Indeks

Kamdi, W dkk. 2007. Model-Model Pembelajaran Inovatif. Malang: Universitas Negeri. Malang.

Kemmis \& Mc. Taggart. 2002. The Action Research Plane. Victoria: Deakin University.

Pusat Pengembangan Profesi Pendidik Badan Pengembangan Sumber Daya Manusia Pendidikan dan Kebudayaan dan Penjaminan Mutu Pendidikan. 2014. Materi Pelatihan Guru Implementasi Kurikulum 2013 Tahun 2014. Disajikan Dalam Workshop Impelentasi Kurikulum 2013, Dinas Pendidikan Daerah Kota Blitar, 26-30 Juni 2014.

Rahardjo, Dwi Ilham. 2012. Model-Model Pembelajaran Cooperative Learning.

Makalah disajikan dalam Workshop Pengembangan Karier Guru dan

Penelitian Tindakan Kelas KKG Gugus 09 Kota Blitar Juni 2012

Rohain, A. 1996. Pengelolaan Kelas. Jakarta: Rineka Cipta. 
Slavin, Robert E. 2009. Cooperative Learning Teori Riset dan Praktek, terj. Lita, Bandung : Nusa Media, 2009.

Rusman. 2010. Model-Model Pembelajaran Mengembangkan Profesionalisme Guru, cet. ke-1, Jakarta: PT. RajaGrafindo Persada, 2010.

Hamdani, Saeful. 2003. Pengembangan Kurikulum Pendidikan Islam. Bandung: Rosdakarya.

Rositawaty, S. 2008. Belajar Ilmu Pengetahuan Alam 4. Jakarta: Pusat Perbukuan, Departemen Pendidikan Nasional.

Sudjana, Nana. 1989. Penilaian Hasil Proses Belajar Mengajar. Bandung : PT. Remaja Rosdakarya.

Wardhani, IGK. 2011. Penelitian Tindakan Kelas. Jakarta: Universitas Terbuka 